\title{
The influence of nutrition on the relationships between gastro-intestinal parasites and their hosts
}

\author{
By T. E. Gibson, Ministry of Agriculture, Fisheries and Food, Central Veterinary \\ Laboratory, New Haw, Weybridge, Surrey
}

Nutrition experiments tend to be laborious and exacting as do those involving parasitic worms. It is understandable, therefore, that experimental work on the nutrition of parasitized animals has been carried out by relatively few workers and in consequence the data upon which we may assess the interaction of nutrition and parasitism are relatively few. Most of the studies in this field have been with gastrointestinal parasites and this review will refer mainly to work on the gastro-intestinal parasites of the domestic animals.

Our knowledge of the nutrition of parasites is at present fragmentary so that there is little information from which it might be possible to deduce the effects a parasite might have on the nutrition of its host. Usually the volume of the parasite burden, even of a heavily infected animal, is small in comparison with the size of the host and it is difficult to believe that the needs of the parasite for carbohydrate, protein or fat exert an appreciable influence on the amounts of these substances available to the host. It is possible, however, that parasites require relatively large quantities of vitamins and trace elements and by preferential absorption from the chyle deprive the host of some of them. It has been shown by Nyberg (I952) that Diphyllobothrium latum is a rich source of cyanocobalamin, and von Bonsdorff \& Gordin (1952) have suggested that the tapeworm absorbs large amounts of this vitamin causing a macrocytic anaemia in the host. This anaemia can be cured by the administration of dried $D$. latum or of cyanocobalamin. More detailed work on the metabolism of nematodes may reveal other instances in which the particular needs of the parasite for vitamins and trace elements conflict with the needs of the host.

\section{Effect of parasitic infection on appetite}

One of the striking effects of gastro-intestinal parasites on their hosts is a depression of appetite. Amongst the first workers to demonstrate this effect were Lucker \& Neumayer (1947) who reported a decrease in hay consumption by sheep 6 weeks after the administration of Bunostomum trigonocephalum larvae. Laurence, Groenewald, Quin, Clark, Ortlepp \& Bosman (195I) working with 7-month-old lambs infected with Haemonchus contortus and Oesophagostomum columbianum demonstrated a distinct depression of appetite from the Ioth day after the administration of infective larvae. Further experiments showed that although the appetite for hay was depressed the total ration of maize, $400 \mathrm{~g} / \mathrm{sheep}$ to one group and $100 \mathrm{~g} / \mathrm{sheep}$ to another, was consumed. These results were supported in part by those of Gibson (1955) who demonstrated that lambs carrying heavy infections of Trichostrongylus axei consumed less hay than uninfected lambs whether they were receiving concentrates or not. He also demonstrated a decreased appetite for concentrates in lambs allowed free access to both hay and concentrated food. In further observations it 
was shown that worm-free animals restricted to the same level of food intake as the infected lambs gained more weight than the latter, demonstrating that anorexia is not the only factor tending to reduce weight gain in infected lambs. Some of these factors will be discussed later, and include reduced digestibility and utilization of the food. Shumard, Bolin \& Eveleth (I957) reported decreased consumption of a pelleted food consisting of lucerne meal, yellow maize, molasses, salt and trace elements, in sheep carrying infections of Haemonchus contortus, Trichostrongylus colubriformis and Nematodirus spathiger. Water consumption was, however, unaffected. Bremner (196I) working with calves artificially infected with Oesophagostomum radiatum observed a rapid reduction of food intake about 4 weeks after infection, followed by a gradual return to the pre-infection level about $\mathrm{r}_{4}$ weeks later. Bremner also noted a superior rate of weight gain in control animals whose diet was restricted to the same level as that of the infected animals, again showing that factors other than anorexia operated in reducing weight gain. Andrews (1938), however, found no difference in food consumption between lambs infected with Cooperia curticei and uninfected control lambs. Similarly Andrews, Kauffman \& Davis (1944) found that infected lambs that did not develop clinical signs did not show any depression of appetite. However, lambs in which clinical trichostrongylosis developed reduced their food intake rapidly after infection; the heavier the infection the more striking was the effect.

The different degree of depression of appetite reported by various workers is probably referable to the severity of the changes produced by the parasite in the gut. When heavy infections of nematodes produce severe inflammation of the gastro-intestinal tract it is understandable that the animal will feel disinclined to eat. In those instances when infection produces relatively little, mild inflammation the effect on appetite may be so small as to be undetectable. It is difficult to see how this effect could be brought about by parasites which do not inhabit the gastrointestinal tract, but its occurrence has apparently not been investigated.

\section{Effect of parasitic infection on digestibility and food utilization}

Stewart $\left(\mathrm{I}_{932-3 a)}\right.$ studied the metabolism of sheep carrying trichostrongylid infections and found that the digestibility of crude protein was reduced but that the digestibility of other components of the ration was not affected except that the digestibility of crude fibre was reduced in instances in which infection was heavy. Stewart postulated that this effect was caused by anti-enzymes, and in a subsequent paper (Stewart, $193^{2-} 3^{b}$ ) described the isolation from nematode tissues of a substance which inhibited the action of proteolytic enzymes. Further work by Shearer \& Stewart (1932-3) showed that nematode infections interfered with calcium and phosphorus metabolism but not with that of sodium or potassium. Franklin, Gordon \& Macgregor (1946) came to similar conclusions by comparing the metabolism of worm-free lambs with that of similar animals artificially infected with $T$. colubriformis. There was a significant depression in protein digestibility and a significantly poorer utilization of calcium and phosphorus. Blood analyses revealed a decline in serum content of calcium, magnesium and phosphorus. These results were not, 
however, supported by Andrews (1938) and Andrews et al. (1944) who could detect no changes in the metabolism of lambs carrying artificial infestations of $C$. curticei and $T$. colubriformis respectively. Spedding (1954) working with lambs carrying subclinical worm burdens of $T$. axei demonstrated a significant depression in digestibility of dry matter. The apparent digestibility of crude protein was significantly lowered in the infected lambs whereas there was no effect on that of the crudefibre fraction. In his experiments Spedding fed the lambs on grass preserved by freezing, hay and crushed oats, and his results probably approximate more closely to conditions at pasture than those of most other workers. Shumard et al. (1957) found $H$. contortus, T. colubriformis and $N$. spathiger infections to reduce the digestibility of protein. It was also found that the lambs became hypophosphataemic and hyperglycaemic.

Although Andrews (1938) and Andrews et al. (1944) were unable to detect any effect of infections with $C$. curtice $i$ and $T$. colubriformis on digestibility, they did observe that these infections reduced the ability of the host to utilize its food properly. Infected animals gained less per unit of food than controls. This same effect was observed by Andrews \& Jones ( 1948 ) in pigs infected naturally with lungworms, ascarids, Strongyloides and whipworms.

The work summarized above shows that the important effects parasites produce on the nutrition of the host are depression of appetite, and decreased digestibility and utilization of the food. The degree to which a parasite influences the nutrition of its host varies with the severity of the clinical effects it produces. Different parasites influence the nutrition of the host in different ways.

\section{Effect of nutrition on the development of parasitism in the host}

Under practical farming conditions it has long been recognized that well-nourished animals resist parasitism better than those inadequately fed. Lucker \& Neumayer (1947) demonstrated that the severity of parasitism was greater in poorly fed animals. A pair of lambs given a poor diet and infected with hookworms developed anaemia and died, whereas a similar pair of lambs given the same number of hookworm larvae but fed on a good diet developed only a slight anaemia. No anaemia developed in uninfected control animals. At post-mortem examination the animals in the poorly fed group were found to be carrying more worms than those in the well-fed group, the severity of the anaemia being related to the number of worms that became established. Laurence et al. (195I) found that an increase of $300 \mathrm{~g} /$ day in the daily grain ration of worm-infested sheep produced a marked superiority in bodyweight, haemoglobin level, fleece weight and wool-fibre thickness. White \& Cushnie (1952), however, were unable to see any difference between two groups of ewes at pasture, one group of which received a daily supplement of oats and linseed cake. It was found, however, that the egg count was higher in the faeces of the lambs when neither they nor their dams received the supplement than when both ewes and lambs received it. The experiments carried out by Gibson (1955), using groups of four lambs, on the effect of worm burden on appetite also included observations on the effect of the plane of nutrition on the effects of parasites. The latter findings 22 (1) 3 
were not published but are here summarized in Tables $\mathbf{I}$ and 2 . It will be seen that during the first I I weeks of the experiment worm-free, well-fed sheep gained $33 \frac{1}{2} \mathrm{lb}$ each whereas infected, well-fed sheep gained only $\mathrm{I} \frac{1}{2} \mathrm{lb}$. Similar worm-free, poorlyfed sheep gained $\frac{1}{2} \mathrm{lb}$ and infected, poorly-fed sheep lost $8 \mathrm{lb}$ each. One death from parasitism occurred in the well-fed, infected group but all four of the poorly-fed, infected sheep died during that period. Table 2 shows that three well-fed lambs killed at the end of the experiment ( 36 weeks after infection) had appreciably lower worm burdens than the poorly fed lambs that died in the course of the experiment. It cannot, however, be argued that fewer worms became established in the better-fed lambs for it is quite conceivable that large numbers of worms may have become established in these animals and subsequently been thrown off.

Table I. Effect of plane of nutrition and heavy infection with T. axei on weight gain and mortality rate in groups of four lambs during 11 weeks after infection

$\begin{array}{lcc}\text { Group } & \begin{array}{c}\text { Mean weight } \\ \text { gain (lb) }\end{array} & \begin{array}{c}\text { No. of } \\ \text { deaths }\end{array} \\ \text { A, full diet, infected } & \mathrm{I} \cdot 5 & \mathrm{I} \\ \text { B, full diet, control } & 33 \cdot 5 & \circ \\ \text { C, low diet, infected } & -8 \cdot 0 & 4 \\ \text { D, low diet, control } & 0 \cdot 5 & \circ\end{array}$

Table 2. Effect of plane of nutrition on the number of 'T. axei found at post-mortem in lambs that had been heavily infected with the worm

(Values for individual lambs)

Group

A, full diet, infected

$C$, low diet, infected

\begin{tabular}{|c|c|c|c|}
\hline \multicolumn{4}{|c|}{ No. of worms } \\
\hline เ8 $000 *$ & $25000 \dagger$ & $500^{*}$ & $13000^{*}$ \\
\hline $37000 \dagger$ & $30000 t$ & $49000 \dagger$ & $32000 \dagger$ \\
\hline
\end{tabular}

No worms were found in full-diet or low-diet controls.

* Killed 36 weeks after infection.

tDied during the first i 1 weeks of the experiment.

A generally deficient diet has been demonstrated by many workers to result in the establishment of a greater worm burden than a full diet. Typical of such experiments is Taylor's (1934) experience that heavier worm burdens were found in sheep receiving straw only or hay only than in sheep receiving hay and concentrates. Some workers have investigated the effect of individual food constituents, and a few examples will serve to illustrate the general picture. Ackert, McIlvaine \& Crawford (I93 I) showed that chickens fed on a diet deficient in vitamin A contained greater numbers of larger Ascaridia galli than control birds. Ackert \& Nolf (I93 I) found greater numbers of $A$. galli in chickens fed on a diet deficient in the vitamin $B$ complex than in chicks fed on a normal diet or a diet supplemented with baker's yeast. Additional protein was found by Ackert $\&$ Beach (I 933) to reduce the numbers of $A$. galli in birds, and later Riedel \& Ackert (1950, I95I) produced evidence that the quality of protein was important in limiting the establishment of $A$. galli. Some mineral substances have also been shown to reduce susceptibility to helminths. 
Clapham (1934) found a calcium-deficient diet to result in the establishment of more Heterakis gallinae than a control one and Harwood \& Luttermoser (1938) found manganese deficiency to increase the susceptibility of chickens to Raillietina cesticillus.

It is important, however, to realize that nutrition may not only modify resistance to infection, but also resistance to the effects of infection. Foster \& Landsberg (1934), for example, have shown that anaemia may be prevented in dogs infected with hookworms by the administration of iron. Kauzal (r933) reported considerable burdens of $H$. contortus, Trichostrongylus sp., Ostertagia sp. and Nematodirus sp. in fat sheep, and similar experiences were recorded by Davey (1936) and Fraser \& Robertson (I937). This phenomenon is of considerable importance in the epidemiology of parasitic disease since animals that are able to tolerate the presence of large numbers of parasites when properly fed may succumb if subsequently the standard of nutrition is decreased. The toleration of a worm burden under conditions of adequate nutrition perpetuates infection on the pastures and again may be responsible for disease under less favourable nutritional conditions. Stewart \& Gordon (1953) have, however, pointed out that factors other than nutrition may operate in the field. They suggest that conditions that produce an abundant supply of herbage may also favour the development of nematode larvae, but when poor nutritive conditions prevail few larvae are available to the sheep. Sheep that ingest few larvae during their early life have less opportunity to develop resistance than those that ingest more larvae under favourable conditions.

\section{Summary}

The presence of gastro-intestinal parasites affects the nutrition of the host by the depression of appetite and a decrease in digestibility of certain food elements. Inefficient utilization of food results in a poorer rate of weight gain per unit of food than that in worm-free animals.

The effects of parasites on their hosts are greater when the standard of nutrition is low and lack of vitamin A and protein seems to be particularly important. A high standard of nutrition may reduce the number of parasites that become established in an animal or may reduce the effects of large numbers which do become established. The latter state is of considerable importance in the epidemiology of parasitic disease.

\section{REFERENCES}

Ackert, J. E. \& Beach, T. D. (r933). Trans. Amer. micr. Soc. 52, 51.

Ackert, J. E., Mcllvaine, M. F. \& Crawford, N. Z. (1931). Amer. F. Hyg. 13, 320.

Ackert, J. E. \& Nolf, L. O. (1931). Amer. F. Hyg. 13, 337.

Andrews, J. S. (1938). F. agric. Res. 57, 349.

Andrews, J. S. \& Jones, D. J. (1948). F. Parasit. 34, 13.

Andrews, J. S., Kauffman, W. \& Davis, R. E. (1944). Amer. Y. vet. Res. 5, 22.

Bremner, K. C. (196r). Aust. F. agric. Res. 12, 498.

Clapham, P. A. (1934). F. Helminth. 12, 123.

Davey, D. G. (1936). F. Helminth. 14, 85 .

Foster, A. O. \& Landsberg, J. W. (1934). Amer. F. Hyg. 20, 259.

Franklin, M. C., Gordon, H. McL. \& Macgregor, C. H. (1946). F. Coun. sci. industr. Res. Aust. 19, 46. Fraser, A. H. H. \& Robertson, D. (1937). F. Helminth. ז5, 53.

Gibson, T. E. (1955). F. comp. Path. 65, 3I7.

Harwood, P. D. \& Luttermoser, G. W. (1938). Proc. helm. Soc. Wash. 5, 6o. 
Kauzal, G. (1933). Aust. vet. F. 9, 179.

Laurence, G. B., Groenewald, J. W., Quin, J. I., Clark, R., Ortlepp, R. J. \& Bosman, S. W. (195I). Onderstepoort F. vet, Sci. 25, no. r, p. I2 r.

Lucker, J. T. \& Neumayer, E. M. (1947). Amer. Ұ. vet. Res. 8, 400.

Nyberg, W. (1952). Acta med. scand. 144, Suppl. 271, p. 68.

Riedel, B. B. \& Ackert, J. E. (1950). Poult. Sci. 29, 437.

Riedel, B. B. \& Ackert, J. E. (195I). Poult. Sci. 30, 497.

Shearer, G. D. \& Stewart, J. (1932-3). Rep. Inst. Anim. Path. Univ. Camb. p. 87.

Shumard, R. F., Bolin, D. W. \& Eveleth, D. F. (1957). Amer. F. vet. Res. 18, 330.

Spedding, C. R. W. (1954). F. comp. Path. 64, 5.

Stewart, D. F. \& Gordon, H. McL. (1953). Aust. F. agric. Res. 4, 340.

Stewart, J. (1932-3a). Rep. Inst. Anim. Path. Univ. Camb. p. 58.

Stewart, J. (1932-3b). Rep. Inst. Anim. Path. Univ. Camb. p. 77.

Taylor, E. L. (1934). F. comp. Path. 47, 235.

von Bonsdorff, B. \& Gordin, R. (1952). Acta med. scand. 142, Suppl. 266, p. 283.

White, E. G. \& Cushnie, G. H. (1952). Brit. f. Nutr. 6, 376.

\section{Nutrition and helminthiasis in chickens}

\section{By L. G. Chubb and D. Wakelin, Houghton Poultry Research Station, Houghton, Huntingdon}

Lapage (1956) lists sixty-nine species of helminths that may be found in the domestic fowl, but of these, only the nematodes, Ascaridia galli, Heterakis gallinarum and Capillaria sp. are of economic importance and probably only $A$. galli and $C$. obsignata are of pathogenic significance. Occasionally cestodes, such as Raillietina and Davainea sp., are found and trematodes very rarely.

Wakelin (1963) has discussed the importance of Capillaria sp. in chickens and in a recent survey has found that its incidence can exceed that of $A$. galli. Heavy infections by either of these helminths produce retardation of growth and stunting in young stock, and a decrease in egg production in laying birds which often become severely emaciated. In contrast, $H$. gallinarum is itself not particularly harmful to the fowl although it is often present in large numbers. Its importance lies in the part it plays in the transmission of the protozoan disease histomoniasis.

The influence of nutrition on experimental infections in general, and on hosthelminth relationships in particular, has been discussed by several groups of workers (Clark, McClung, Pinkerton, Price, Schneider \& Trager, I949; Chandler, I953; Hunter, 1953; Scrimshaw, Taylor \& Gordon, I959). Any appraisal of the problem must take into account the following aspects: (I) the virulence of the parasite, the size of the infective dose and route of entry, (2) the host that becomes infected, and in this respect genetics, age and sex are important, (3) the nutritional status of the host, (4) the nature of the resistance produced. Consequently, the host-parasite interrelationship is never static but complex and dynamic with either organism capable of producing constant changes in the other. Thus, any particular combination of the host and parasite can produce effects which range from no observable interaction to a serious disease which may result in the death of the host. Between these two extremes lies a whole range of interactions which can be influenced by nutrition. 